\title{
Revisiting CDK Inhibitors for Treatment of Glioblastoma Multiforme
}

\author{
Dorota Lubanska $^{1} \cdot$ Lisa Porter ${ }^{1}$
}

Published online: 21 March 2017

(c) The Author(s) 2017. This article is an open access publication

\begin{abstract}
Despite extensive efforts and continual progress in research and medicine, outcomes for patients with highgrade glioma remain exceptionally poor. Over the past decade, research has revealed a great deal about the complex biology behind glioma development, and has brought to light some of the major barriers preventing successful treatment. Glioblastoma multiforme (GBM) (stage 4 astrocytoma) is a highly dynamic tumour and one of the most extreme examples of intratumoural heterogeneity, making targeting with specific therapeutics an inefficient and highly unpredictable goal. The cancer stem cell hypothesis offers a new view on the possible mechanisms dictating the heterogeneous nature of this disease and contributes to our understanding of glioma resistance and recurrence. Revealing cell division characteristics of initiating cell populations within GBM may represent novel treatment targets and/or the effective repurposing of existing therapies. In this review, we discuss the potential role of targeting the cyclin-dependent kinases (CDKs) driving this specific population. We also describe developments using multi-omic approaches that may aid in stratifying patient populations for CDK inhibitor therapy.
\end{abstract}

Lisa Porter

lporter@uwindsor.ca

1 Department of Biological Sciences, University of Windsor, 401 Sunset Ave, Biology rm. 201, Windsor, ON N9B 3P4, Canada

\section{Key Points}

Despite advances in understanding the initiation and progression of glioblastoma multiforme, prognosis remains poor.

Promising pre-clinical data targeting the cyclindependent kinases (CDKs) have failed to yield similar results in the clinic.

Advances in stratifying patient populations and in CDK drug design offer new hope for this therapeutic direction.

\section{Overview}

Glioblastoma multiforme (GBM) is one of the most aggressive cancers and the most common adult primary brain malignancy. Despite efforts to improve GBM survival, optimally treated patients achieve a median survival of only 14 months, with a $26 \%$ 2-year survival rate $[1,2]$. GBM presents with higher complexity than previously thought, with tremendous intratumoural heterogeneity comprising cells of distinct genetic, phenotypic and morphological profiles. Among the heterogeneous cellular mass, specific clones are able to evade therapy, leading to cancer progression or relapse [3-7]. Imaging methods and classical histopathological examination currently remain the gold standard in glioma diagnostics [7]. Integration of phenotypic and genotypic parameters in the World Health Organization (WHO) classification has improved the accuracy of diagnosis and prognosis for central nervous system (CNS) tumours; however, these are seldom used to 
direct new therapy for GBM $[8,9]$. Standard multimodal therapy involves surgery and/or radiation with concurrent chemotherapy using the alkylating agent temozolomide (TMZ). Considering the disease heterogeneity and subjective nature of the histological assessment, current diagnostic and treatment approaches are clearly insufficient to improve patient outcomes for GBM.

Dissecting the biological nature of brain tumour heterogeneity truly began with the discovery of cancer stem cells in the hematopoietic system [10]. While the initial cell of origin remains a subject of debate, it is clear that regardless of the original source, populations of cells capable of self-renewal can exist, which can recapitulate the heterogeneity of the parental tumour in a xenograft model $[11,12]$. These cells are often referred to as brain tumour initiating cells (BTICs) to avoid the rigidity imposed by the cancer stem cell hypothesis. Research profiling the pathways and genes involved in the aggressive behaviour of BTICs is offering new opportunities to develop effective treatments targeting this aggressive cell population [3-5]. This review will focus on the potential utility of targeting unique cell cycle characteristics in this population and will ask how to reliably predict the driving pathways given the heterogeneous nature of GBM.

\section{Current Glioblastoma Multiforme (GBM) Classification}

\subsection{Genomic Classification of GBM}

Recent efforts to characterize both low- and high-grade gliomas have demonstrated that characterizing according to molecular features may be more important than classical histopathological-defined grading [13, 14]. In high-grade glioma, the number of mutational events occurring is staggering, and getting a handle on the hierarchy of these events represents a significant hurdle. By sequencing 22,661 genes, Parsons et al. established that on average over 45 different mutations characterize a single GBM tumour [15]. Work performed by the Cancer Genome Atlas Research Network [16], involving 91 GBM samples, established that 223 genes were affected by 453 non-silent somatic mutations [6]. The detailed analysis of 601 genes revealed a mutational spectrum with noted aberrations in $\mathrm{p} 53$, retinoblastoma $(\mathrm{Rb})$ and tyrosine kinase pathways [16]. This has since been expanded on to include exome sequencing of 291 glioblastomas, RNA sequencing of 164 samples and copy number, DNA methylation, protein, messenger RNA (mRNA) and microRNA (miRNA) expression profiles of over 500 GBMs [17]. Using genomic profiling to classify tumours at a molecular level is one way to organize this chaos, and is quickly becoming an indispensable tool in modern medicine. In a 2006 study, based on the core gene expression as well as copy number data from 107 samples, Phillips et al. determined three molecular signatures defining prognostic subclasses of highgrade glioma, designated proneural (PN), mesenchymal (MES) and proliferative (PROLIF) [18]. Almost 90\% of grade III tumours belonged to the PN subtype, with this group representing a younger population with a better prognosis. GBM on the other hand could be classified into each of the three subclasses. In a later advance of this work, Verhaak and colleagues further classified GBM into four subtypes using a 840-gene signature [6]. In this work, PN and MES subtypes overlapped with previously identified populations; however, the PROLIF group was further subdivided into a classical and neural signature. Multiple efforts have followed to establish alternative categorization; however, the mutual exclusivity of PN and MES subtypes continued to emerge as a robust signature. The magnitude of the differences between these subtypes suggests separate disease entities, potentially due to a distinct cell of origin.

Interestingly, the defined genomic subtypes parallel stages in forebrain neural development and expression of tissue specific markers, suggesting that processes driving glioma progression resemble those of neurogenesis [18]. The PN subtype tends to associate with secondary GBM and is characterized by markers of normal brain and neurogenesis. Whereas the more aggressive GBM subtypes, PROLIF and MES, express genes indicative of cell proliferation, angiogenesis and wound healing, signatures indicative of poor prognosis in epithelial tumour types [18]. Ample literature suggests that the PN subtype is driven by an early mutation of TP53, regulating consistent genetic changes through tumour progression [19-21], whereas complex aberrations in multiple molecular pathways seem to underlie the MES subtype [21-26]. Hence, genomic subtyping of high-grade glioma has provided a prognostic classification scheme as well as the beginnings of a network of processes that may drive these specific forms of GBM to initiate and progress. This advance in classifying GBM has contributed to a better understanding of GBM pathology and offers significant potential for the advance of therapeutic strategies; however, a genomic classification approach alone is restricted in its ability to predict the actual response of a tumour to treatment. This is due in part to the extreme heterogeneity of the disease and the knowledge that individual cases of GBM comprise individual subclones belonging to these GBM subtypes [9], as we will discuss.

\subsection{Proteomic/Phosphoproteomic Classification of GBM}

The availability of proteomic signatures and protein biomarkers determined in tumour biopsies, plasma or 
bodily fluids throughout the treatment course has enormous prognostic potential and ideally can aid in treatment decisions. Approaches comparing protein expression patterns of brain tumours to normal matching tissue allows for assessment of potential disease biomarkers with clinical utility. Proteomic profiling includes not only large scale analysis of protein expression, but also assessment of the interactome and post-translational modifications. In a recent study Wei et al. utilized a quantitative and multiplex single-cell barcode chip method [27] to perform phosphoproteomic analysis in vivo in a patient-derived GBM model of resistance [28]. The authors showed that in response to treatment, cells failed to undergo changes that would support genetic selection, but rather rapidly re-wired protein signalling pathways as a dominant mechanism of resistance. This study provides solid evidence that a multiomics approach is essential for molecular assessment of tumour resistance and is necessary for subsequent predicted on-target intervention to arrest tumour growth in vivo. This study also revealed that the timing of analysis may be critical, where deep genetic changes may occur upon longterm exposure to therapy and drive selection of treatment resistant cell populations, while rapid adaptation develops through proteins and their phosphorylation networks.

\section{Detecting Brain Tumour Initiating Cells (BTICs) Using Multi-omic Approaches}

Extensive investigation employing genomic subtyping is crucial to determine whether we can accurately classify the characteristics of cancers that can arise from select BTICs to guide therapeutic decisions. The observed cellular hierarchy in glioma resembles hierarchy of normal brain development and homeostasis, suggesting that ontogeny is reflected in cancer [29]. The complicated nature of brain tumours is mimicked after brain complexity, with cellular dynamics regulated by the niche and responsive to microenvironment maintenance cues [30]. Unlike normal brain tissue where generation of subsequent committed cell populations is a stage-specific and clearly defined process, in glioma, distinguishing the dynamics between self-renewing BTICs at the top of the hierarchy and their progenitor populations is still a work in progress.

Phillips et al. established clear genomic parallels between brain tumourigenesis and forebrain neurogenic development, giving insight and better understanding of the character of possible glioma origin and disease evolution and progression [18]. The established subtype model with demonstrated differences in phosphatase and tensin homologue (PTEN) status and Notch signalling supports the notion that glioma aggressiveness relies on processes that regulate cell fate choices during neurogenesis. The speculated model of glioma initiation and progression based on the determined genomic signatures suggests that established subtypes arise from a common cell of origin, but the MES subtype remains more stem-like, PROLIF resembles a transit amplifying state, while the PN subtype adopts a phenotype of committed neural precursors characterized by low proliferation rates. The responsiveness of both neural stem cells as well as transit amplifying cells to epidermal growth factor (EGF) was established previously [31]. Both MES and PROLIF subtypes are characterized by amplification of epidermal growth factor receptor (EGFR) and showed ability to propagate neurospheres in response to EGF + fibroblast growth factor (FGF)-containing media, suggesting that established subclasses may represent distinct differentiation stages of glioma and that their stem-like character can be predicted by genomic profiling.

\section{BTICs in Drug Resistance}

The therapy-mediated selection of resistant clones is supported by ample evidence in the literature [10, 29, 32-34], and it relates to the cancer stem cell model of intratumoural heterogeneity where cancer stem cells divide asymmetrically to self-renew and create more differentiated progeny. Due to environmental pressure induced by chemo- and/or radiotherapy the heterogeneous mass is exposed to, the most resistant clone survives and expands, leading to relapse.

Extensive evidence suggests that glioma recurrence truly relies on the stem-like BTIC population; however, more investigation is required to establish whether a model of selection, interconversion to a cancer stem cell model, or their co-existence is at the source of glioma expansion after treatment [35-38]. In opposition to the selection model, a study involving long-term exposure to therapeutic concentrations of TMZ reported expansion of glioma stem cell pools in cell lines, xenograft models and primary patientderived cultures, where these stem cell-like populations were newly converted from non-cancer stem cell populations [37]. Demonstrated data reveal that observed interconversion under $\mathrm{TMZ}$ influence leads to generation of highly invasive and tumourigenic BTIC populations characterized by expression of parental molecular markers. The presented data argue against the selection model and suggest that glioma stemness and subsequent relapse can rely on cellular plasticity. Moreover, the induction of plasticity by routinely used chemotherapeutic agents such as TMZ brings in a question about the molecular mechanism and spectrum of the observed interconversion, occurring perhaps under different chemotherapy treatments. It is evident that a better understanding of the genomic and cellular dynamics behind glioma heterogeneity and application of 
the knowledge in preclinical and clinical studies is of high importance to assure evasion of patient relapse and to provide successful clinical outcomes.

\section{Detecting BTICs During Drug Resistance}

The extensive and multidimensional search for the glioma cell of origin, as well as cell type triggering the disease recurrence throughout the heterogeneous mass of the tumour, recently adopted a single-cell analysis approach. A group led by Dirks utilized single cell-derived clonal analysis in efforts to establish a link between genomic and functional heterogeneity [9]. They revealed genetic signatures correlating with specific functional behaviour of individual clones derived from a single tumour that exhibited distinct proliferation, differentiation and chemotherapy resistance characteristics. Importantly, the study demonstrated that TMZ-resistant clones exist in an untreated tumour $a b$ initio, without the requirement for TMZ-mediated selective pressure or induction of plasticity, described earlier. A parallel study by Soeda et al., performed on four clones obtained from an individual patient, not only confirmed the functional diversity described by Dirks, but managed to link more stem-like phenotypes to enhanced invasiveness of the clones when xenografted to a mouse model [39]. Although the analysed clones showed differences upon surface marker profiling and diverse responsiveness to EGFR inhibitors, the authors failed to correlate the marker and drug sensitivity profile with clone phenotypes in their sample size [39]. The novel findings show that single glioma tumours contain multiple clones of distinct response to therapeutic agents and suggest a novel avenue of the individualized approach where clone-specific therapy should be tested and developed for efficient glioma treatment.

Using the single-cell analysis approach in a phosphoproteomics study, Wei et al. reported no changes in stemness marker gene expression between therapy responsive and recurrent/resistant tumours [28]. This study argued that acquired drug resistance was not mediated by expansion of an aggressive BTIC pool. They presented evidence of an adaptive mechanism of rapid modification of protein networks, supporting the importance of examining proteomics at the source of glioma heterogeneity and recurrence.

Investigation into the phosphoproteome dynamics of glioma-initiating cells upon EGF stimulation, using a powerful combination of high resolution mass spectrometry and single isotope labelling of amino acids (SILAC), demonstrated upregulation and downregulation of hundreds of phosphorylation sites on proteins mainly responsible for signal transduction and transcription as well as changes in phosphorylation status on nestin and vimentin stem cell markers and proteins involved in pathways regulating stemness [40]. The reported results suggest not only the role of EGF in regulation of phosphoprotein network re-wiring, but also point at potential analogous effects upon treatment of glioma with EGFR antagonists, underscoring the necessity of differential phosphoproteome profiling of resistant BTICs.

\section{Potential for the Novel Targeting of BTICs Using Cyclin-Dependent Kinase Inhibitors (CKIs)}

\subsection{CKI Drugs in GBM Treatment}

A plethora of tumourigenic events in brain cancer drive proliferation through the recruitment of cyclin-dependent kinases (CDKs) in the G1 phase of the cell cycle. Furthermore, the hallmark of genomic instability in GBM is related to perturbations in the $S$ phase and G2/M transition controlled by CDKs. Understanding which CDKs are activated in GBM and whether there are unique alterations to these complexes that are utilized to override protective cell cycle checkpoints is one approach that may provide utility in battling brain tumours in a clinical setting. Preclinical studies and clinical trials over the past two decades, testing the effectiveness of CDK inhibitors (CKIs), have generated mixed results, with a non-definite conclusion with regard to the utility of these agents.

Initially developed CKIs were designed to exhibit a broad spectrum of action against CDKs (pan-CKIs). The most extensively studied first-generation agent, flavopiridol, induces a cell cycle arrest in G1 and G2 phases in vitro, causes significant cytotoxic effects due to inhibition of CDK7 and CDK9 in vivo, and demonstrates low levels of clinical activity [41]. In a study by Hayashi et al., flavopiridol showed promising results in combination with TMZ, as it enhanced cytotoxicity in a glioblastoma cell line and sensitized xenografted mice to TMZ [42]. TMZ resistance was acquired through stimulation of G2 checkpoint-mediated DNA repair activity. Although, the presented data suggested that use of CKI suppressed the DNA repair mechanisms at the $\mathrm{G} 2 / \mathrm{M}$ transition and prevented TMZ resistance, a study involving orthotopic xenograft models is required to further evaluate the potential preclinical efficacy of the proposed combination in glioma therapy.

To increase the selectivity of the CKIs towards CDK1 and CDK2, several compounds were developed as secondgeneration CKIs (Table 1). This generation of inhibitors exhibited promising results in a pre-clinical setting; however, only a few were able to pass through phase I of clinical trials. Dinaciclib, a potent inhibitor developed to 
Table 1 Reported CKIs with antiglioma effects

\begin{tabular}{|c|c|c|c|c|c|c|}
\hline CKI & Targets & $\begin{array}{l}\text { BBB } \\
\text { penetration }\end{array}$ & Therapeutic effect against glioma & $\begin{array}{l}\text { Glioma } \\
\text { therapy } \\
\text { combination } \\
\text { tested }\end{array}$ & $\begin{array}{l}\text { Glioma- } \\
\text { specific } \\
\text { clinical } \\
\text { trials }\end{array}$ & References \\
\hline $\begin{array}{l}\text { Roscovitine } \\
\text { (Seliciclib, } \\
\text { CYC202) }\end{array}$ & $\begin{array}{l}\text { CDK5/p35; Cdc2/ } \\
\text { Cyclin B; CDK2/ } \\
\text { Cyclin E; CDK2/ } \\
\text { Cyclin A }\end{array}$ & Yes & $\begin{array}{l}\text { Increased sensitivity to therapy induced } \\
\text { apoptosis in vitro }\end{array}$ & TRAIL & $\begin{array}{l}\text { Not } \\
\text { reported }\end{array}$ & {$[61-63]$} \\
\hline $\begin{array}{l}\text { Milciclib } \\
\text { (PHA- } \\
848125)\end{array}$ & $\begin{array}{l}\text { CDK2/Cyclin A; } \\
\text { CDK7/Cyclin H; } \\
\text { CDK4/Cyclin D1 }\end{array}$ & Yes & $\begin{array}{l}\text { Inhibition of cell proliferation, } \\
\text { downregulation of CDK } 4 / \mathrm{Rb} \text { transduction } \\
\text { pathway markers; induction of cell death } \\
\text { through autophagy in vitro and in vivo }\end{array}$ & TMZ & $\begin{array}{l}\text { Not } \\
\text { reported }\end{array}$ & {$[64,65]$} \\
\hline $\begin{array}{l}\text { SNS-032 } \\
\text { (BMS- } \\
\text { 387032) }\end{array}$ & $\begin{array}{l}\text { CDK7/Cyclin H; } \\
\text { CDK2/Cyclin A; } \\
\text { CDK2/Cyclin E; } \\
\text { CDK9/Cyclin T }\end{array}$ & $\begin{array}{l}\text { Not } \\
\text { reported }\end{array}$ & $\begin{array}{l}\text { Inhibition of hypoxia induced U87MG cell } \\
\text { invasion, block of HIF11 } \alpha \text {-expression } \\
\text { in vitro }\end{array}$ & Not reported & $\begin{array}{l}\text { Not } \\
\text { reported }\end{array}$ & {$[66-68]$} \\
\hline $\begin{array}{l}\mathrm{SCH} 727965 \\
\text { (dinaciclib) }\end{array}$ & $\begin{array}{l}\text { CDK2; CDK5; CDK1; } \\
\text { CDK9 }\end{array}$ & $\begin{array}{l}\text { Not } \\
\text { reported }\end{array}$ & $\begin{array}{l}\text { Induction of apoptosis in synergy with } \\
\text { ABT-737 or ABT-263, small-molecule } \\
\text { Bcl-2/Bcl-xL antagonists }\end{array}$ & ABT-737 & $\begin{array}{l}\text { Not } \\
\text { reported }\end{array}$ & {$[43,69]$} \\
\hline $\begin{array}{l}\text { PD-0332991 } \\
\text { (palbociclib) }\end{array}$ & $\begin{array}{l}\text { CDK4/Cyclin D3; } \\
\text { CDK4/Cyclin D1; } \\
\text { CDK6/Cyclin D2; } \\
\text { CDK2/Cyclin E2 }\end{array}$ & Yes & $\begin{array}{l}\text { In vitro G1 cell cycle arrest and induction of } \\
\text { senescence; suppression of GBM } \\
\text { xenograft growth in vivo }\end{array}$ & $\begin{array}{l}\text { TMZ, } \\
\text { radiotherapy }\end{array}$ & Yes & {$[70,71]$} \\
\hline PHA-767491 & Cdc7; CDK9; CDK2 & No & $\begin{array}{l}\text { Decreased cell proliferation and viability, } \\
\text { induction of apoptosis in vitro }\end{array}$ & Not reported & $\begin{array}{l}\text { Not } \\
\text { reported }\end{array}$ & {$[72,73]$} \\
\hline Purvalanol A & $\begin{array}{l}\text { Cdc2/Cyclin B; } \\
\text { CDK2/Cyclin E; } \\
\text { CDK2/Cyclin A; } \\
\text { CDK4/Cyclin D1 }\end{array}$ & Yes & $\begin{array}{l}\text { Inhibition of GBM stem-like cells invasion } \\
\text { in vitro and in vivo }\end{array}$ & Not reported & $\begin{array}{l}\text { Not } \\
\text { reported }\end{array}$ & {$[74,75]$} \\
\hline $\begin{array}{l}\text { LY2835219 } \\
\text { (abemaciclib) }\end{array}$ & CDK4; CDK6 & Yes & $\begin{array}{l}\text { Tumour xenograft growth suppression } \\
\text { in vivo }\end{array}$ & TMZ & Yes & {$[45,76]$} \\
\hline
\end{tabular}

$B B B$ blood-brain barrier, $C D K$ cyclin-dependent kinase, $C K I$ cyclin-dependent kinase inhibitor, $G B M$ glioblastoma multiforme, $T M Z$ temozolomide, TRAIL tumour necrosis factor-related apoptosis-inducing ligand

specifically inhibit CDK1, CDK2, CDK5 and CDK9, inhibits proliferation of human glioma cell lines independent of p53 mutation status [43]. Combination of dinaciclib with multiple conventional chemotherapeutic agents as well as growth signalling inhibitors failed to induce cell death. The synergistic apoptotic response was found when dinaciclib was combined with Bcl-2/Bcl-xL inhibitors [43], suggesting the importance of screening the effects of CKIs in combination with different therapeutics to determine their potency and seek molecular-based reasons for the favourable response.

Highly selective CDK4/6 inhibitors, palbociclib and abemaciclib, induce cell cycle blockage through inhibition of Rb1 phosphorylation [44]. The cyclin D1-CDK4/6-Rb pathway is altered in nearly $80 \%$ of human gliomas and is one of the three most perturbed pathways [16, 17], suggesting both inhibitors as promising agents in glioma treatment. In in vivo studies, palbociclib and abemaciclib demonstrated an advantage in combination with TMZ and radiotherapy [44]. Importantly, both compounds have the ability to cross the blood-brain barrier [44]. Investigation into their anti-proliferative effects within a brain is warranted. Abemaciclib has recently moved into phase I clinical trials for several solid cancers, including glioblastoma [45].

\subsection{Battling Weaknesses of CKI Specificity}

The observed clinical failure of first-generation CKIs is likely attributed to their low specificity, which is, in consequence, followed by difficulty dissecting the actual molecular response in vivo. The lack of specificity of this generation of CKIs also complicates any efforts to stratify the patient population, design effective combination strategies, and modify the existing compound. Secondgeneration inhibitors offer promise; however, one then must consider the possible redundancies of other CDKs and/or extreme lethality. Notably, knockouts of the G1/S CDK, CDK2, despite having redundancy for normal developmental programmes, demonstrate that CDK2 is 
essential for transformation driven by several classical oncogenes [46, 47].

\subsection{Non-canonical Cyclin-Dependent Kinase Activators}

An interesting idea for an alternate mechanism of CDK targeting is to target CDKs bound to non-canonical binding partners [48]. Since current design of synthetic CKIs relies on the CDK protein conformation bound to known canonical cyclins, one can speculate that CDK non-cyclin binding partners can continue to stimulate $\mathrm{CDK}$ activation in the presence of synthetic CKI inhibition. One family of Speedy/RINGO proteins has been well established as CDK binding partners with no homology to cyclins [49]. All mammalian Speedy/RINGO proteins demonstrate diverse tissue expression, have been shown to bind CDKs in vivo, and differ in specific CDK binding preferences. One family member, Spy1A1 (gene SPDYA) has the capacity to bind to both CDK2 and CDK1, and has a demonstrated role in neural malignancies, including human GBM [50, 51]. Spy1A1 exhibits surprising differences in CDK activation in that Spy1-bound CDKs are activated in the absence of CDK-activating kinase (CAK)-mediated phosphorylation on the T-loop (Thr-160/161) [48, 52]. Importantly, Spy1A1-CDK complexes are less sensitive to the inhibitory phosphorylation on Thr-14/Tyr-15 on the CDK, and are also less susceptible to $\mathrm{p} 21^{\mathrm{Cip} 1}$ cell cycle inhibitor action [53]. Hence, the presence of Spy1A1 protein may perpetuate an active CDK in the face of senescence-inducing stimuli-such as oncogenic mutations and DNA mutations-presenting a very attractive target and potential combination therapy with other cytotoxic approaches. Preclinical data using patient-derived GBM suggest that this may be a powerful approach to target the BTIC population in human GBM [50]. Analogically, proteins p35 and p39, lacking cyclin sequence homology, are essential binding partners of CDK5. Moreover, p35 and p39 are found exclusively in the brain [54, 55], which is consistent with established roles of CDK5 in processes of neurogenesis, neuronal maturation, neurodegeneration and brain cancer [56-58]. CDK5 does not require phosphorylation on the T-loop, and it becomes readily activated by binding to its partner proteins [59]. Currently, there is no work done on the potential importance of this family of proteins as a therapeutic target and/or on the efficacy of current approaches.

In summary, non-cyclin CDK activators constitute a group of novel potential targets in designing therapies directed against CDK activity in human glioma. Targeting selected Speedy/RINGO proteins through abrogation of CDK binding or specific inhibition of the complex may improve the efficacy of standard and available synthetic CKIs, as well as potentially enhance the specificity of the treatment as a monotherapy or in combination with conventional chemotherapy agents. Due to the brain tissue specificity of the CDK5/p35/p39 complex, eradication of binding between CDK5 and its known partner proteins can contribute to development of therapies selectively directed towards neural malignancies. As new proteins are being discovered to drive CDK5 activity in different malignancies [60], high-throughput screens of novel binding partners of CDKs emerge as a new and important avenue in seeking specific protein targets. Obtaining highly specific and potent CKIs may advance success in glioma therapy.

\section{Conclusion}

High-grade gliomas remain among the most challenging malignancies to treat, and patient outcomes continue to be very poor. Advances in technology have revolutionized our understanding of glioma biology, revealing the true complexity and dynamics of brain tumour heterogeneity. The discovery of stem-like populations of cells in brain cancer has become a central axis integrating glioma research. Attempts to address critical questions on cancer stem cell characteristics and their role in glioma therapy resistance and recurrence stimulated a new era of singlecell analysis, including genomics, proteomics and their link to functional heterogeneity. Ultimately, targeting the driving population remains a key goal. New opportunities for therapeutic intervention include synthetic second-/ third-generation targeted CKIs. To utilize these approaches, researchers must determine how to integrate and interpret information about cancer stem cell-driven dynamics with steady-state tumour genomic, proteomic and phosphoproteomic profiles. Ultimately, this would require a global effort to combine many areas of expertise and share resources and databases to fully utilize and push the limits of existing technology. Implementing a proper personalized, targeted approach such as this requires this orchestrated effort to cascade down into the clinic. While the technologies and ideas exist, funding and organization of such a global effort is certainly a futuristic ideal.

Author contributions All authors equally contributed to this paper with regard to conception and design of the study, literature review and analysis, drafting and critical revision and editing, and final approval of the final version.

\section{Compliance with Ethical Standards}

Funding This work is supported by the Canadian Cancer Society Research Institute Innovation to Impact Grant \# 703877. 
Conflict of interest The authors have no conflicts to declare.

Open Access This article is distributed under the terms of the Creative Commons Attribution-NonCommercial 4.0 International License (http://creativecommons.org/licenses/by-nc/4.0/), which permits any noncommercial use, distribution, and reproduction in any medium, provided you give appropriate credit to the original author(s) and the source, provide a link to the Creative Commons license, and indicate if changes were made.

\section{References}

1. Stupp R, Mason WP, van den Bent MJ, Weller M, Fisher B, Taphoorn MJ, Belanger K, Brandes AA, Marosi C, Bogdahn U, et al. Radiotherapy plus concomitant and adjuvant temozolomide for glioblastoma. N Engl J Med. 2005;352:987-96.

2. Stupp R, Hegi ME, Mason WP, van den Bent MJ, Taphoorn MJ, Janzer RC, Ludwin SK, Allgeier A, Fisher B, Belanger K, et al. Effects of radiotherapy with concomitant and adjuvant temozolomide versus radiotherapy alone on survival in glioblastoma in a randomised phase III study: 5-year analysis of the EORTCNCIC trial. Lancet Oncol. 2009;10:459-66.

3. Beug $\mathrm{H}$. Breast cancer stem cells: eradication by differentiation therapy? Cell. 2009;138:623-5.

4. Klonisch T, Wiechec E, Hombach-Klonisch S, Ande SR, Wesselborg S, Schulze-Osthoff K, Los M. Cancer stem cell markers in common cancers - therapeutic implications. Trends Mol Med. 2008;14:450-60.

5. Kim SH, Ezhilarasan R, Phillips E, Gallego-Perez D, Sparks A, Taylor D, Ladner K, Furuta T, Sabit H, Chhipa R, et al. Serine/ threonine kinase MLK4 determines mesenchymal identity in glioma stem cells in an NF-kappaB-dependent manner. Cancer Cell. 2016;29:201-13.

6. Verhaak RG, Hoadley KA, Purdom E, Wang V, Qi Y, Wilkerson MD, Miller CR, Ding L, Golub T, Mesirov JP, et al. Integrated genomic analysis identifies clinically relevant subtypes of glioblastoma characterized by abnormalities in PDGFRA, IDH1, EGFR, and NF1. Cancer Cell. 2010;17:98-110.

7. Yin L, Zhang L. Correlation between MRI findings and histological diagnosis of brainstem glioma. Can $\mathrm{J}$ Neurol Sci. 2013;40:348-54.

8. Louis DN, Ohgaki H, Wiestler OD, Cavenee WK, Burger PC, Jouvet A, Scheithauer BW, Kleihues P. The 2007 WHO classification of tumours of the central nervous system. Acta Neuropathol. 2007;114:97-109.

9. Meyer M, Reimand J, Lan X, Head R, Zhu X, Kushida M, Bayani J, Pressey JC, Lionel AC, Clarke ID, et al. Single cell-derived clonal analysis of human glioblastoma links functional and genomic heterogeneity. Proc Natl Acad Sci USA. 2015;112:851-6.

10. Lapidot T, Sirard C, Vormoor J, Murdoch B, Hoang T, CaceresCortes J, Minden M, Paterson B, Caligiuri MA, Dick JE. A cell initiating human acute myeloid leukaemia after transplantation into SCID mice. Nature. 1994;367:645-8.

11. Choi SA, Lee JY, Phi JH, Wang KC, Park CK, Park SH, Kim SK. Identification of brain tumour initiating cells using the stem cell marker aldehyde dehydrogenase. Eur J Cancer. 2014;50:137-49.

12. Singh SK, Hawkins C, Clarke ID, Squire JA, Bayani J, Hide T, Henkelman RM, Cusimano MD, Dirks PB. Identification of human brain tumour initiating cells. Nature. 2004;432:396-401.

13. Brat DJ, Verhaak RG, Aldape KD, Yung WK, Salama SR, Cooper LA, Rheinbay E, Miller CR, Vitucci M, Morozova O, et al. Comprehensive, integrative genomic analysis of diffuse lower-grade gliomas. N Engl J Med. 2015;372:2481-98.
14. Eckel-Passow JE, Lachance DH, Molinaro AM, Walsh KM, Decker PA, Sicotte H, Pekmezci M, Rice T, Kosel ML, Smirnov IV, et al. Glioma groups based on 1p/19q, IDH, and TERT promoter mutations in tumors. N Engl J Med. 2015;372:2499-508.

15. Parsons DW, Jones S, Zhang X, Lin JC, Leary RJ, Angenendt P, Mankoo P, Carter H, Siu IM, Gallia GL, et al. An integrated genomic analysis of human glioblastoma multiforme. Science. 2008;321:1807-12.

16. TGCA. Comprehensive genomic characterization defines human glioblastoma genes and core pathways. Nature. 2008;455:1061-8.

17. Brennan CW, Verhaak RG, McKenna A, Campos B, Noushmehr H, Salama SR, Zheng S, Chakravarty D, Sanborn JZ, Berman SH, et al. The somatic genomic landscape of glioblastoma. Cell. 2013;155:462-77.

18. Phillips HS, Kharbanda S, Chen R, Forrest WF, Soriano RH, Wu TD, Misra A, Nigro JM, Colman H, Soroceanu L, et al. Molecular subclasses of high-grade glioma predict prognosis, delineate a pattern of disease progression, and resemble stages in neurogenesis. Cancer Cell. 2006;9:157-73.

19. Cooper LA, Gutman DA, Long Q, Johnson BA, Cholleti SR, Kurc T, Saltz JH, Brat DJ, Moreno CS. The proneural molecular signature is enriched in oligodendrogliomas and predicts improved survival among diffuse gliomas. PLoS One. 2010;5:e12548.

20. Ducray F, Idbaih A, de Reynies A, Bieche I, Thillet J, Mokhtari K, Lair S, Marie Y, Paris S, Vidaud M, et al. Anaplastic oligodendrogliomas with $1 \mathrm{p} 19 \mathrm{q}$ codeletion have a proneural gene expression profile. Mol Cancer. 2008;7:41.

21. Johnson BE, Mazor T, Hong C, Barnes M, Aihara K, McLean CY, Fouse SD, Yamamoto S, Ueda H, Tatsuno K, et al. Mutational analysis reveals the origin and therapy-driven evolution of recurrent glioma. Science. 2014;343:189-93.

22. Lv B, Yang X, Lv S, Wang L, Fan K, Shi R, Wang F, Song H, Ma $X$, Tan X, et al. CXCR4 signaling induced epithelial-mesenchymal transition by PI3K/AKT and ERK pathways in glioblastoma. Mol Neurobiol. 2014;52:1263-8.

23. Carro MS, Lim WK, Alvarez MJ, Bollo RJ, Zhao X, Snyder EY, Sulman EP, Anne SL, Doetsch F, Colman H, et al. The transcriptional network for mesenchymal transformation of brain tumours. Nature. 2010;463:318-25.

24. Mahabir R, Tanino M, Elmansuri A, Wang L, Kimura T, Itoh T, Ohba Y, Nishihara H, Shirato H, Tsuda M, Tanaka S. Sustained elevation of Snail promotes glial-mesenchymal transition after irradiation in malignant glioma. Neuro Oncol. 2014;16:671-85.

25. Mao P, Joshi K, Li J, Kim SH, Li P, Santana-Santos L, Luthra S, Chandran UR, Benos PV, Smith L, et al. Mesenchymal glioma stem cells are maintained by activated glycolytic metabolism involving aldehyde dehydrogenase $1 \mathrm{~A} 3$. Proc Natl Acad Sci USA. 2013;110:8644-9.

26. Myung JK, Choi SA, Kim SK, Wang KC, Park SH. Snail plays an oncogenic role in glioblastoma by promoting epithelial mesenchymal transition. Int J Clin Exp Pathol. 2014;7:1977-87.

27. Shi Q, Qin L, Wei W, Geng F, Fan R, Shin YS, Guo D, Hood L, Mischel PS, Heath JR. Single-cell proteomic chip for profiling intracellular signaling pathways in single tumor cells. Proc Natl Acad Sci USA. 2012;109:419-24.

28. Wei W, Shin YS, Xue M, Matsutani T, Masui K, Yang H, Ikegami S, Gu Y, Herrmann K, Johnson D, et al. Single-cell phosphoproteomics resolves adaptive signaling dynamics and informs targeted combination therapy in glioblastoma. Cancer Cell. 2016;29:563-73.

29. Reya T, Morrison SJ, Clarke MF, Weissman IL. Stem cells, cancer, and cancer stem cells. Nature. 2001;414:105-11.

30. Hanahan D, Weinberg RA. Hallmarks of cancer: the next generation. Cell. 2011;144:646-74.

31. Doetsch F, Petreanu L, Caille I, Garcia-Verdugo JM, AlvarezBuylla A. EGF converts transit-amplifying neurogenic precursors 
in the adult brain into multipotent stem cells. Neuron. 2002;36:1021-34.

32. Blagosklonny MV. An anti-aging drug today: from senescencepromoting genes to anti-aging pill. Drug Discov Today. 2007;12:218-24.

33. Milas L, Hittelman WN. Cancer stem cells and tumor response to therapy: current problems and future prospects. Semin Radiat Oncol. 2009;19:96-105.

34. Vermeulen L, de Sousa e Melo F, Richel DJ, Medema JP. The developing cancer stem-cell model: clinical challenges and opportunities. Lancet Oncol. 2012;13:e83-9.

35. Bao S, Wu Q, McLendon RE, Hao Y, Shi Q, Hjelmeland AB, Dewhirst MW, Bigner DD, Rich JN. Glioma stem cells promote radioresistance by preferential activation of the DNA damage response. Nature. 2006;444:756-60.

36. Liu G, Yuan X, Zeng Z, Tunici P, Ng H, Abdulkadir IR, Lu L, Irvin D, Black KL, Yu JS. Analysis of gene expression and chemoresistance of CD133+ cancer stem cells in glioblastoma. Mol Cancer. 2006;5:67.

37. Auffinger B, Tobias AL, Han Y, Lee G, Guo D, Dey M, Lesniak MS, Ahmed AU. Conversion of differentiated cancer cells into cancer stem-like cells in a glioblastoma model after primary chemotherapy. Cell Death Differ. 2014;21:1119-31.

38. Jackson M, Hassiotou F, Nowak A. Glioblastoma stem-like cells: at the root of tumor recurrence and a therapeutic target. Carcinogenesis. 2015;36:177-85.

39. Soeda A, Hara A, Kunisada T, Yoshimura S, Iwama T, Park DM. The evidence of glioblastoma heterogeneity. Sci Rep. 2015;5:7979.

40. Kozuka-Hata H, Nasu-Nishimura Y, Koyama-Nasu R, Ao-Kondo H, Tsumoto K, Akiyama T, Oyama M. Phosphoproteome of human glioblastoma initiating cells reveals novel signaling regulators encoded by the transcriptome. PLoS One. 2012;7:e43398.

41. Bose P, Simmons GL, Grant S. Cyclin-dependent kinase inhibitor therapy for hematologic malignancies. Expert Opin Investig Drugs. 2013;22:723-38.

42. Hayashi T, Adachi K, Ohba S, Hirose Y. The CDK inhibitor flavopiridol enhances temozolomide-induced cytotoxicity in human glioma cells. J Neurooncol. 2013;115:169-78.

43. Jane EP, Premkumar DR, Cavaleri JM, Sutera PA, Rajasekar T, Pollack IF. Dinaciclib, a cyclin-dependent kinase inhibitor promotes proteasomal degradation of Mcl-1 and enhances ABT-737mediated cell death in malignant human glioma cell lines. J Pharmacol Exp Ther. 2016;356:354-65.

44. Raub TJ, Wishart GN, Kulanthaivel P, Staton BA, Ajamie RT, Sawada GA, Gelbert LM, Shannon HE, Sanchez-Martinez C, De Dios A. Brain exposure of two selective dual CDK4 and CDK6 inhibitors and the antitumor activity of CDK4 and CDK6 inhibition in combination with temozolomide in an intracranial glioblastoma xenograft. Drug Metab Dispos. 2015;43:1360-71.

45. Patnaik A, Rosen LS, Tolaney SM, Tolcher AW, Goldman JW, Gandhi L, Papadopoulos KP, Beeram M, Rasco DW, Hilton JF, et al. Efficacy and safety of abemaciclib, an inhibitor of CDK4 and CDK6, for patients with breast cancer, non-small cell lung cancer, and other solid tumors. Cancer Discov. 2016;6:740-53.

46. Santamaria D, Barriere C, Cerqueira A, Hunt S, Tardy C, Newton $\mathrm{K}$, Caceres JF, Dubus P, Malumbres M, Barbacid M. Cdk1 is sufficient to drive the mammalian cell cycle. Nature. 2007;448:811-5.

47. Molenaar JJ, Ebus ME, Geerts D, Koster J, Lamers F, Valentijn LJ, Westerhout EM, Versteeg R, Caron HN. Inactivation of CDK2 is synthetically lethal to MYCN over-expressing cancer cells. Proc Natl Acad Sci USA. 2009;106:12968-73.

48. Dinarina A, Perez LH, Davila A, Schwab M, Hunt T, Nebreda AR. Characterization of a new family of cyclin-dependent kinase activators. Biochem J. 2005;386:349-55.
49. Lenormand JL, Dellinger RW, Knudsen KE, Subramani S, Donoghue DJ. Speedy: a novel cell cycle regulator of the G2/M transition. EMBO J. 1999;18:1869-77.

50. Lubanska D, Market-Velker BA, deCarvalho AC, Mikkelsen T, Fidalgo da Silva E, Porter LA. The cyclin-like protein Spy1 regulates growth and division characteristics of the CD133+ population in human glioma. Cancer Cell. 2014;25:64-76.

51. Lubanska D, Porter LA. The atypical cell cycle regulator Spy 1 suppresses differentiation of the neuroblastoma stem cell population. Oncoscience. 2014;1:336-48.

52. Cheng A, Xiong W, Ferrell JE Jr, Solomon MJ. Identification and comparative analysis of multiple mammalian Speedy/Ringo proteins. Cell Cycle. 2005;4:155-65.

53. Karaiskou A, Perez LH, Ferby I, Ozon R, Jessus C, Nebreda AR. Differential regulation of $\mathrm{Cdc} 2$ and $\mathrm{Cdk} 2$ by RINGO and cyclins. J Biol Chem. 2001;276:36028-34.

54. Tsai LH, Delalle I, Caviness VS Jr, Chae T, Harlow E. p35 is a neural-specific regulatory subunit of cyclin-dependent kinase 5 . Nature. 1994;371:419-23.

55. Lew J, Huang QQ, Qi Z, Winkfein RJ, Aebersold R, Hunt T, Wang JH. A brain-specific activator of cyclin-dependent kinase 5 . Nature. 1994;371:423-6.

56. Cheung ZH, Ip NY. Cdk5: a multifaceted kinase in neurodegenerative diseases. Trends Cell Biol. 2012;22:169-75.

57. Lagace DC, Benavides DR, Kansy JW, Mapelli M, Greengard P, Bibb JA, Eisch AJ. Cdk5 is essential for adult hippocampal neurogenesis. Proc Natl Acad Sci USA. 2008;105:18567-71.

58. Nikolic M, Dudek H, Kwon YT, Ramos YF, Tsai LH. The cdk5/ p35 kinase is essential for neurite outgrowth during neuronal differentiation. Genes Dev. 1996;10:816-25.

59. Otyepka M, Bartova I, Kriz Z, Koca J. Different mechanisms of CDK5 and CDK2 activation as revealed by CDK5/p25 and CDK2/cyclin A dynamics. J Biol Chem. 2006;281:7271-81.

60. Xu S, Li X, Gong Z, Wang W, Li Y, Nair BC, Piao H, Yang K, $\mathrm{Wu}$ G, Chen J. Proteomic analysis of the human cyclin-dependent kinase family reveals a novel CDK5 complex involved in cell growth and migration. Mol Cell Proteom. 2014;13:2986-3000.

61. Kim EH, Kim SU, Shin DY, Choi KS. Roscovitine sensitizes glioma cells to TRAIL-mediated apoptosis by downregulation of survivin and XIAP. Oncogene. 2004;23:446-56.

62. Meijer L, Borgne A, Mulner O, Chong JP, Blow JJ, Inagaki N, Inagaki M, Delcros JG, Moulinoux JP. Biochemical and cellular effects of roscovitine, a potent and selective inhibitor of the cyclin-dependent kinases cdc2, cdk2 and cdk5. Eur J Biochem. 1997;243:527-36.

63. Menn B, Bach S, Blevins TL, Campbell M, Meijer L, Timsit S. Delayed treatment with systemic (S)-roscovitine provides neuroprotection and inhibits in vivo CDK5 activity increase in animal stroke models. PLoS One. 2010;5:e12117.

64. Albanese C, Alzani R, Amboldi N, Degrassi A, Festuccia C, Fiorentini F, Gravina G, Mercurio C, Pastori W, Brasca M, et al. Anti-tumour efficacy on glioma models of PHA-848125, a multikinase inhibitor able to cross the blood-brain barrier. Br J Pharmacol. 2013;169:156-66.

65. Brasca MG, Amboldi N, Ballinari D, Cameron A, Casale E, Cervi G, Colombo M, Colotta F, Croci V, D'Alessio R, et al. Identification of N,1,4,4-tetramethyl-8-\{[4-(4-methylpiperazin-1yl)phenyl]amino -4,5-dihydro-1H-py razolo[4,3-h]quinazoline3-carboxamide (PHA-848125), a potent, orally available cyclin dependent kinase inhibitor. J Med Chem. 2009;52:5152-63.

66. Ali MA, Reis A, Ding LH, Story MD, Habib AA, Chattopadhyay A, Saha D. SNS-032 prevents hypoxia-mediated glioblastoma cell invasion by inhibiting hypoxia inducible factor-1alpha expression. Int J Oncol. 2009;34:1051-60.

67. Chen R, Wierda WG, Chubb S, Hawtin RE, Fox JA, Keating MJ, Gandhi V, Plunkett W. Mechanism of action of SNS-032, a novel 
cyclin-dependent kinase inhibitor, in chronic lymphocytic leukemia. Blood. 2009;113:4637-45.

68. Conroy A, Stockett DE, Walker D, Arkin MR, Hoch U, Fox JA, Hawtin RE. SNS-032 is a potent and selective CDK 2, 7 and 9 inhibitor that drives target modulation in patient samples. Cancer Chemother Pharmacol. 2009;64:723-32.

69. Parry D, Guzi T, Shanahan F, Davis N, Prabhavalkar D, Wiswell D, Seghezzi W, Paruch K, Dwyer MP, Doll R, et al. Dinaciclib (SCH 727965), a novel and potent cyclin-dependent kinase inhibitor. Mol Cancer Ther. 2010;9:2344-53.

70. Fry DW, Harvey PJ, Keller PR, Elliott WL, Meade M, Trachet E, Albassam M, Zheng X, Leopold WR, Pryer NK, Toogood PL. Specific inhibition of cyclin-dependent kinase 4/6 by PD 0332991 and associated antitumor activity in human tumor xenografts. Mol Cancer Ther. 2004;3:1427-38.

71. Michaud K, Solomon DA, Oermann E, Kim JS, Zhong WZ, Prados MD, Ozawa T, James CD, Waldman T. Pharmacologic inhibition of cyclin-dependent kinases 4 and 6 arrests the growth of glioblastoma multiforme intracranial xenografts. Cancer Res. 2010;70:3228-38.

72. Erkan EP, Dinc M, Eren E, Allmer J, Yalcin T, Genc S. Abstract: A cell division cycle 7-related protein kinase inhibitor suppresses glioblastoma cell growth in vitro. In: XII European meeting on glial cells in health and disease. 2015.
73. Montagnoli A, Valsasina B, Croci V, Menichincheri M, Rainoldi S, Marchesi V, Tibolla M, Tenca P, Brotherton D, Albanese C, et al. A Cdc7 kinase inhibitor restricts initiation of DNA replication and has antitumor activity. Nat Chem Biol. 2008;4:357-65.

74. Gray NS, Wodicka L, Thunnissen AM, Norman TC, Kwon S, Espinoza FH, Morgan DO, Barnes G, LeClerc S, Meijer L, et al. Exploiting chemical libraries, structure, and genomics in the search for kinase inhibitors. Science. 1998;281:533-8.

75. Li Y, Rogoff HA, Keates S, Gao Y, Murikipudi S, Mikule K, Leggett D, Li W, Pardee AB, Li CJ. Suppression of cancer relapse and metastasis by inhibiting cancer stemness. Proc Natl Acad Sci USA. 2015;112:1839-44.

76. Sanchez-Martinez C, Gelbert LM, Shannon H, De Dios A, Staton B, Ajamie RT, Sawada G, Wishart GN, Raub TJ. Abstract B234: LY2835219, a potent oral inhibitor of the cyclin-dependent kinases 4 and $6(\mathrm{CDK} 4 / 6)$ that crosses the blood-brain barrier and demonstrates in vivo activity against intracranial human brain tumor xenografts. In: AACR-NCI-EORTC international conference: molecular targets and cancer therapeutics-Nov 12-16, 2011, San Francisco, CA. 2011. 